\title{
Resource-use efficiency in US aquaculture: farm-level comparisons across fish species and production systems
}

\author{
C. R. Engle ${ }^{1}$, G. Kumar ${ }^{2}$, J. van Senten ${ }^{3, *}$ \\ ${ }^{1}$ Engle-Stone Aquatic\$ LLC, Adjunct Faculty, VA Seafood AREC, Virginia Polytechnic Institute and State University, \\ Hampton, Virginia 23669, USA \\ ${ }^{2}$ Department of Wildlife, Fisheries, and Aquaculture, Delta Research and Extension Center, Mississippi State University, \\ Stoneville, Mississippi 38776, USA \\ ${ }^{3}$ VA Seafood AREC, Virginia Polytechnic Institute and State University, Hampton, Virginia 23669, USA
}

\begin{abstract}
Understanding farm-level efficiencies of resource use is critical in comparisons of the sustainability of aquaculture production systems. We developed a set of practical resource-use efficiency metrics to calculate and compare resource-use efficiency with resource-cost efficiency across major species and production systems in US aquaculture. Results showed that no one production system used all resources most efficiently. Intensive pond production of channel catfish Ictalurus punctatus demonstrated the greatest efficiency in the use of water, energy, labor, management, and capital resources, while RAS production was most efficient in terms of land and feed use. Among the wide array of pond scenarios examined, more intensive scenarios generally were more efficient in terms of several metrics, but economic sustainability also depends upon business models that effectively meet differing demand requirements of customers. Thus, less intensive production systems were economically sustainable in areas with relatively abundant land and water resources available at lower cost. Labor efficiencies varied widely across scenarios analyzed. Given increasing concerns related to the availability of labor for aquaculture farming in the USA, greater attention to the efficiency of labor on farms is warranted. The metrics used were aligned with common farm management tools (e.g. enterprise budgets) that allow for ease of use by farms and researchers to assess effects on comparative resource-use efficiencies of new farming practices and technologies under development.
\end{abstract}

KEY WORDS: Resource-use efficiency $\cdot$ Resource-cost efficiency $\cdot$ US aquaculture $\cdot$ Recirculating aquaculture system $\cdot$ RAS $\cdot$ Pond production

\section{INTRODUCTION}

Sustainability of aquaculture, while once an obscure idea, has become a commonly accepted societal goal (UN 1992, FAO 1999, 2011, Engle 2019c). Despite a robust literature, there is little consensus on a definition of 'sustainability' (Boyd et al. 2020), nor on systems and farming practices that are 'sustainable.'

The sustainability literature has evolved from concepts such as carbon/ecological footprints to data-

${ }^{*}$ Corresponding author: jvansenten@vt.edu intensive life cycle analysis (LCA) (Henriksson et al. 2012, Cao et al. 2013), joint data envelopment (SamuelFitwi et al. 2012), and 'emergy' analysis (Brown \& Herendeen 1996). The number of LCA studies has increased with the commercial availability of LCA software. Concerns have been raised about the lack of comprehensive farm-level datasets required (Henriksson et al. 2012) for accurate modeling and to meet ISO requirements (ISO 14044; ISO 2006). Farm samples were too small in the few LCA studies based on farm

() The authors 2021. Open Access under Creative Commons by Attribution Licence. Use, distribution and reproduction are unrestricted. Authors and original publication must be credited. 
data to be statistically representative of the overall population $^{1}$ (Aubin et al. 2009). Most LCA analyses rely on models (Cao et al. 2013) based on an extensive array of generalized and, at times, heroic, assumptions that likely misrepresent individual farm realities and have low statistical precision (Boyd et al. 2017). Nevertheless, LCA models have been used to draw conclusions about the relative 'sustainability' of species and production systems (Henriksson et al. 2015, Yacout et al. 2016, Hilborn et al. 2018). The lack of transparency of methodologies, underlying assumptions, and characterization of datasets have prevented replication of results (Philis et al. 2019). An egregious example is that of Hilborn et al. (2018), who neglected to report that the data from which 'catfish' were judged to be 'highest impact' were primarily for production of Pangasius $^{2}$. US catfish production has repeatedly been classified as a highly sustainable form of food production (Seafood Watch 2017, Tucker \& Hargreaves 2008).

There appears to be a clear need for comprehensive farm-level data to resolve contradictory results in the literature related to systems and farming practices that are better choices to meet the global need for increased food production in a sustainable manner (Engle \& D'Abramo 2016). Some studies have implied that less intensive production is 'more sustainable' (Costa-Pierce 2010, Cao et al. 2011, Samuel-Fitwi et al. 2012), while others have shown that more intensive farming scores higher on sustainability metrics than less intensive systems, despite the latter being viewed as 'closer to nature' (Lazard et al. 2014, Boyd et al. 2017 , 2018). Osmundsen et al. (2020) further reported the need to incorporate economic considerations in sustainability discussions.

An emerging focus in the literature has been on resource-use efficiency (Boyd et al. 2007, 2017, Boyd \& McNevin 2015, Chatvijitkul et al. 2017a, Engle et al. 2017). A number of studies (Papatryphon et al. 2004, Pelletier et al. 2009, Cao et al. 2011, Jonell \& Henriksson 2015) have shown that natural resource use and negative environmental impacts were concentrated at the farm level. Thus, while sustainability concepts tend to be broader than just resource-use efficiency, a growing body of literature suggests that attention to the efficiency of use of resources at the farm level may be a practical approach to enhancing sustainability by reducing negative environmental impacts. To be measurable at the farm level, however, metrics must be well aligned with farm recordkeeping systems. Most indicators discussed in the literature (e.g. Boyd 1987, Boyd et al. 2007, Chatvijitkul et al. 2017b, Valenti et al. 2018) cannot be imple- mented in a practical way on farms. Enterprise budgets are standard farm management tools (Engle 2010, 2019a, Barry \& Ellinger 2012, Kay et al. 2012) that are well aligned with accounting conventions and software. Farm records of fish sold and inputs used can be readily included in enterprise budgets.

In previous work, farm data collected from national surveys for major sectors of US aquaculture (catfish, trout, baitfish, feeder fish ${ }^{3}$, largemouth bass Micropterus salmoides for foodfish) were used to develop enterprise budgets for several commonly observed production scales (Engle et al. 2020). To include recirculating aquaculture systems (RASs) in the analysis, additional budgets were modeled using capital and labor structures as reported by Boulet et al. (2010), Liu et al. (2016), and Bjorndal \& Tusvik (2017, 2019) and yields and feed conversion ratios reported by Good et al. (2010), Davidson et al. (2014), Cleveland \& Summerfelt (2016) and Crouse et al. (2018) ${ }^{\underline{4}}$. Profitability was compared, but not resource-use efficiencies or cost efficiencies of resource use.

The main contribution of this paper is to show how the incorporation of metrics that are well aligned with a common farm-level management tool such as enterprise budgets can shed light on comparative resource-use efficiencies as well as the associated resource-cost efficiencies. Specific objectives of this study were: (1) to develop a series of resource-use efficiency metrics measurable at the farm level; (2) to compare resource-use efficiencies across pond and raceway production systems and RASs; and (3) to compare resource-cost efficiencies across the same systems.

\section{MATERIALS AND METHODS}

\subsection{Scenarios}

Scenarios selected included a variety of ponds, raceways, and RASs, with an emphasis on the major species raised in the USA (USDA-NASS 2019). Catfish Ictalurus punctatus, the leading finfish species raised

\footnotetext{
1 A 'population' is a statistical term that refers to the group, in this case a group of farms, about which the researcher intends to draw conclusions

$\underline{2}$ It is possible that some data for Clarias production were included

$\underline{3}$ 'Feeder fish' are fish sold to aquarium hobbyists to feed to carnivorous aquarium fish

${ }^{4}$ There are too few RAS farms in the USA from which to collect farm data and preserve confidentiality
} 
in the USA, are most commonly farmed in open, static (no flow-through) earthen ponds (Kumar et al. 2020a), as are largemouth bass Micropterus salmoides raised for food (Engle 2019b). The second-leading finfish species raised in the USA, trout (primarily Oncorhynchus mykiss, but also Salmo trutta, Salvelinus fontinalis, and $O$. clarkii), is most commonly raised in concrete raceways with constant water flow-through, whereas baitfish, feeder goldfish Carassius auratus, and sportfish (including M. salmoides, Lepomis macrochirus, and Pomoxis spp. among others) are most commonly raised in open, static, earthen ponds (Stone et al. 2016, 2019). The scenarios for this analysis included the most common management practices and degree of production intensity as determined by previous surveys of US aquaculture farms (primarily those reported by Kumar et al. 2020a for catfish, Engle et al. 2019 for trout, and van Senten \& Engle 2017 for baitfish, feeder goldfish, and sportfish). For example, van Senten \& Engle (2017) found that minnows sold for baitfish, goldfish for feeder fish, and sportfish for stocking were raised much less intensively than were largemouth bass and catfish raised for foodfish. Scenarios for pond production included 3 farm sizes $(32,125.5$, and $599.2 \mathrm{ha}$ ) of 2 types of baitfish minnows (golden shiners Notemigonus crysoleucas, fathead minnows Pimephales promelas), goldfish production for sale as feeder fish, sportfish, largemouth bass production for foodfish, and 2 of the most commonly observed catfish farm management scenarios (multiple-batch ${ }^{\underline{5}}$ production of channel catfish stocked at 19800 fish ha $^{-1}$ with $6.6 \mathrm{~kW} \mathrm{ha}^{-1}$ aeration and single-batch production of hybrid catfish ( $\left(\right.$ I. punctatus $\times 0^{7} I$. furcatus) stocked at 24700 fish ha ${ }^{-1}$ with intensive aeration, $13.8 \mathrm{~kW}$ $\mathrm{ha}^{-1}$ ). Data for the pond scenarios were taken from Kumar et al. (2016), Kumar \& Engle (2017b), van Senten \& Engle (2017), and Engle (2019b). Four scenarios for raceway production of rainbow trout $O$. mykiss were included (trout raised for foodfish at scales of 27200 and $106600 \mathrm{~kg} \mathrm{yr}^{-1}$; and trout raised for recreational markets at scales of 17700 and $83900 \mathrm{~kg} \mathrm{yr}^{-1}$ ), based on data from a national survey of US trout farms (Engle et al. 2019).

RAS scenarios were developed despite the lack of sufficient numbers of commercial RAS in the USA from which to obtain sufficient farm-level data. Thus, the scenarios for Atlantic salmon Salmo salar, rainbow trout, and tilapia Oreochromis spp. were based on cost and labor structures reported by Boulet et al. (2010), Liu et al. (2016), and Bjorndal \& Tusvik (2017, 2019). The scenarios included production scales of $4500,45400,453500$, and $4535000 \mathrm{~kg} \mathrm{yr}^{-1}$, to encompass the range of the few commercial RASs in the
USA but remain within the limits of the studies from which cost and labor structures were used. While net pen production of salmon has been the focus of many LCAs, there are too few salmon net pen farms in the USA from which to draw farm data and preserve confidentiality and hence salmon net pen farms were not included in this analysis.

\subsection{Resource-use and resource-cost metrics}

Sets of resource-use efficiency metrics were developed based on: (1) the types of resources essential to aquaculture production and to previous empirical work, with special attention paid to those highlighted by Boyd et al. (2017) and Valenti et al. (2018). Resources that are essential inputs for food production generally include: land, labor, capital ${ }^{\underline{6}}$, water, and energy (Engle 2010, 2019a, Barry \& Ellinger 2012, Kay et al. 2012). For finfish, feed is clearly a critical input. The acceptance of metrics to use in the analysis was based on whether they could be calculated from farm enterprise budgets as maintained by farmers. Those that would require outside consultants for additional testing or other measurements were rejected. The resource-use metrics selected included total land area, water footprint, energy use (electricity and fuel), and feed use in aquaculture. While several studies have calculated 'embodied' energy use in various production inputs and facilities (Brown \& Herendeen 1996, Chatvijitkul et al. 2017a), this present analysis focused on direct use of inputs that can be monitored readily from farm data. More efficient use of an input on farms will increase the efficiency of embodied energy used to produce that input. Resource-use efficiencies, or indicators of resource productivity, were calculated as the $\mathrm{kg}$ of fish produced per unit of each resource (Table 1), and resource-cost efficiencies as the cost (in US\$) incurred for each resource unit, expressed as US $\$ \mathrm{~kg}^{-1}$ of fish produced (Table 2). Individual metrics and the underlying assumptions are detailed in Tables $1 \& 2$.

\footnotetext{
5 Multiple-batch production is a catfish production system in which cohorts of fingerlings are stocked each spring but harvest of market-sized fish ( $>0.567 \mathrm{~kg})$ continues from fall of that year into the next year even after stocking the second year's cohort; thus, the pond includes multiple size cohorts, or 'batches,' of fish at any given time

$\underline{6}$ 'Capital' in economics, is the resource or input required to construct production and marketing facilities such as ponds, raceways, RASs, water supply systems, grading sheds, trucks, tractors, and other equipment
} 
Table 1. Calculations of resource-use efficiency metrics. FTE: full-time equivalent

\begin{tabular}{|c|c|}
\hline Resource & Metric calculated \\
\hline Land & $\begin{array}{l}\mathrm{kg} \text { fish produced per ha of total land }{ }^{\mathrm{a}} \text { in farm } \\
\mathrm{kg} \text { of fish produced per water footprint }\end{array}$ \\
\hline Water & of water ${ }^{c}$ \\
\hline Ener & $9 y^{d}$ \\
\hline or \& management & $\begin{array}{l}\mathrm{kg} \text { fish produced per FTE of labor } \\
\mathrm{kg} \text { fish produced per FTE of management }\end{array}$ \\
\hline Capital & $\mathrm{kg}$ fish produced per annual $\$$ of total capital \\
\hline Feed (feed conversion ratio) & \\
\hline \multicolumn{2}{|c|}{ 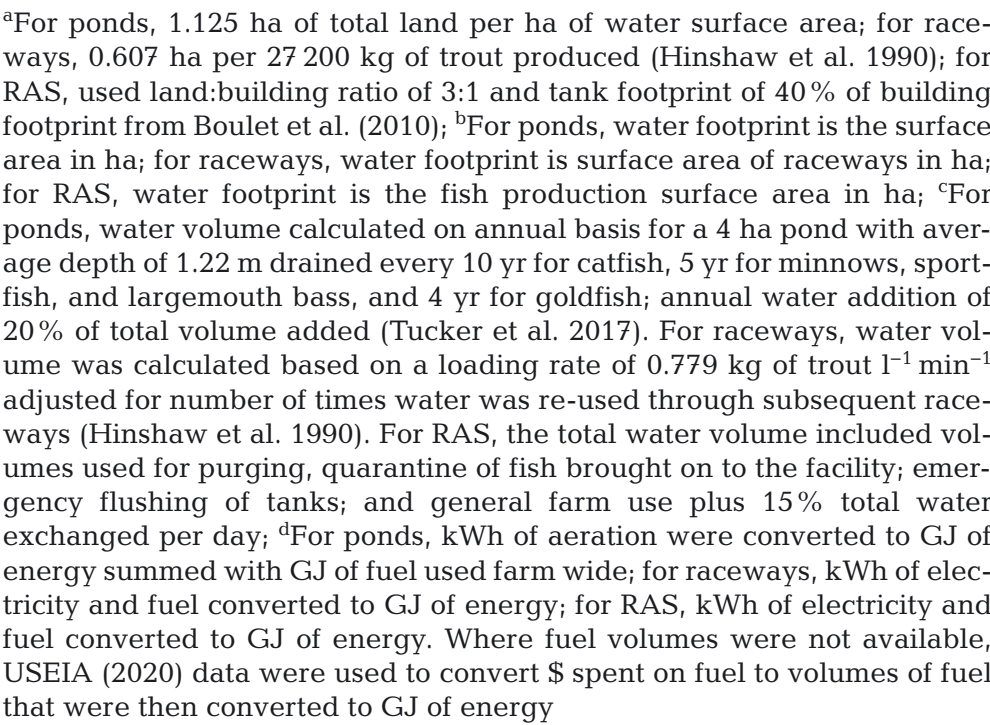 } \\
\hline
\end{tabular}

Table 2. Calculations of resource-cost efficiency metrics

\begin{tabular}{|c|c|}
\hline Type of resource cost & $\begin{array}{l}\text { Metric calculated } \\
\text { (per kg fish produced) }\end{array}$ \\
\hline Land & Land cost ${ }^{\mathrm{a}}$ \\
\hline Water & Water cost ${ }^{b}$ \\
\hline Energy & Energy cost (electricity plus fuel) \\
\hline Labor \& management & $\begin{array}{l}\text { Labor cost } \\
\text { Management cost }\end{array}$ \\
\hline Capital & $\begin{array}{l}\text { Total capital cost }{ }^{\mathrm{a}} \\
\text { Feed cost }\end{array}$ \\
\hline
\end{tabular}

Land-use efficiency was calculated based on total land used for the farm. For pond-based farms, the total land used represents 1.125 ha for each ha of pond area. For raceways, the 0.607 ha of land reported by Hinshaw et al. (1990) to be required for production of $27200 \mathrm{~kg}$ of trout was used. For RAS, values from Boulet et al. (2010) were used to calculate the land area, based on the reported relationship of the tank footprint constituting $40 \%$ of the total building footprint and 3:1 land:building ratio. Land-cost efficiency was calculated by dividing the annualized value of land (USDA-NASS 2018) by the weight $(\mathrm{kg})$ of fish produced for each scenario.

Water-use efficiency was measured by the weight $(\mathrm{kg})$ of fish produced divided by the water footprint. The water footprint of ponds was measured by first calculating the volume of water in a typical 4 ha pond with an average depth of $1.22 \mathrm{~m}$. The total water volume was annualized by dividing by the average number of years between pond draining (every $10 \mathrm{yr}$ for catfish, 5 yr for minnows, sportfish, and largemouth bass, and $4 \mathrm{yr}$ for goldfish) and summed with the $20 \%$ annual replacement value from Tucker et al. (2017). For raceways, the loading rate of $0.779 \mathrm{~kg}$ of trout $\mathrm{l}^{-1} \mathrm{~min}^{-1}$ from Hinshaw et al. (1990, in press) was used to calculate the annual volume of water, assuming 3 re-uses of water as it flows through 3 sets of raceways. For RAS, the total water volume was calculated based on the water volume required for growout, smolts for the 3 larger RAS sizes, purging off-flavors from market-sized fish, quarantine of fish brought onto the facility, emergency flushing of tanks, and other farm uses (Timmons 2002, Davidson et al. 2014) summed with $15 \%$ total water volume exchanged each day. The water-cost efficiency was calculated by dividing the total cost of pumping water to refill production units by the $\mathrm{kg}$ of fish produced for each scenario. Most water used in freshwater aquaculture production is pumped from groundwater sources by farms with private use rights to that water. The exception is raceways that primarily use gravityflow surface water sources.

Energy-use efficiency was measured by the $\mathrm{kg}$ of fish produced divided by the energy use in gigajoules (GJ). For pond-based scenarios, the aeration rate in $\mathrm{kWh}$ was converted to GJ of energy and summed with the quantity of fuel use, expressed in GJ. Similarly, for raceways and RAS, the sum of kWh of electricity and the quantity of fuel were converted to GJ of energy. For budgets in which only annual fuel cost was available (but not quantity), the fuel cost was converted to volume using average fuel prices from the US Energy Information Administra- 
tion (USEIA 2020) before converting to GJ of energy. The energy-cost efficiency was calculated as the sum of the total cost of electricity and fuel divided by the $\mathrm{kg}$ of fish produced for each scenario.

Labor- and management-use efficiencies were measured by dividing the weight (in $\mathrm{kg}$ ) of fish sold by the full-time equivalents (FTEs) in labor and management, respectively. One FTE is equivalent to $1 \mathrm{em}$ ployee who works full-time (2080 hours per year) and year-round. Use of FTEs enables accounting for the variable working hours of part-time and seasonal employees. To calculate total FTEs, the hours worked by part-time and seasonal employees were summed, divided by 2080 (www.opm.gov), and added to the number of full-time employees. The labor-cost efficiency was measured by dividing the sum of total labor wages paid (full-time year-round, full-time seasonal, and parttime) by the weight of fish sold. Similarly, management productivity was measured and compared across farm scenarios as the weight (in $\mathrm{kg}$ ) of fish sold divided by the FTEs of management. The management-cost efficiency was measured by dividing the sum of wages paid for management by the weight of fish sold.

The productivity of capital used was measured as the weight (in $\mathrm{kg}$ ) of fish sold divided by the annualized cost of total investment capital. The capital-cost efficiency was calculated by dividing the annualized cost of total investment capital by the weight (in $\mathrm{kg}$ ) of fish sold.

Feed efficiency was measured as the feed conversion ratio, calculated as the $\mathrm{kg}$ of feed fed divided by the $\mathrm{kg}$ of fish sold. While fish nutritionists often convert calculations of feed conversion to dry weights and also adjust for mortalities and initial stocking biomass, from the perspective of a farmer, the feed conversion ratio that is meaningful is the ratio of the feed fed and the weight of fish sold. The feed-cost efficiency was calculated by dividing the total expenditures on feed by the weight (in kg) of fish sold.

The enterprise budgets developed by Engle et al. (2020) were used for this analysis, with complete details on values for all production parameters for each scenario available at www.arec.vaes.vt. edu/arec/virginia-seafood/research.html. The budget spreadsheets were amended by including formulas for each of the metrics listed in Tables $1 \& 2$.

The enterprise budgets were developed with standardized values (national averages) for key items, including land values, labor wages, management salaries, and interest rates ${ }^{\underline{7}}$. While these values vary by geographic region and from farm to farm within regions, standardizing these values was necessary for valid comparisons of productivity and efficiency across production systems. Feed costs, however, were not standardized across the budgets. The feed conversion ratios and yield productivity that drive many of the metrics calculated are directly related to the use of appropriate feed formulations that meet the nutritional needs of the fish raised. Average costs of the commercial feed fed to each species were used in the respective budgets (Engle et al. 2020), available at: www.arec.vaes.vt.edu/arec/virginia-seafood/ research.html.

\section{RESULTS}

\subsection{Land}

The RASs exhibited the greatest productivity of land use with the greatest values of weight of fish produced per unit area of land used (in kg of fish ha ${ }^{-1}$ of land) (Fig. 1a). The calculations included total land used, accounting for the size of buildings that accommodate movement of fish from tank to tank, and total land area that includes space for feed bins, delivery trucks, docks, roads, and other necessary infrastructure. Raceway production of trout was the second-most productive use of land and was followed by that of ponds. Land productivity of RASs on average was 4.5 times greater than that of raceway production and 89 times greater than that of pond production.

Of the various pond scenarios, hybrid catfish production (with intensive aeration) was the most productive, followed by channel catfish (multiple batch), then largemouth bass for foodfish, goldfish, sportfish, golden shiners, and fathead minnows (Fig. 1a). Overall, hybrid catfish production with intensive aeration was 1.7 times more productive in terms of land use than multiple-batch channel catfish production, 3.7 times more productive than largemouth bass production for foodfish, 13 times more productive than goldfish, 31 times more productive than sportfish and golden shiners, and 63 times more productive than fathead minnows.

Resource-cost efficiency of total land for the various farm scenarios showed that the scenarios with the lowest fish yield $\left(\mathrm{kg} \mathrm{ha}^{-1}\right)$ had the greatest annualized land cost per $\mathrm{kg}$ of fish produced (Fig. 1b). Thus, the greatest land cost per kg of fish produced was that of fathead minnows, followed by golden

\footnotetext{
${ }^{7}$ For details on specific values, the full enterprise budgets are available at: www.arec.vaes.vt.edu/arec/virginia-seafood/ research.html
} 

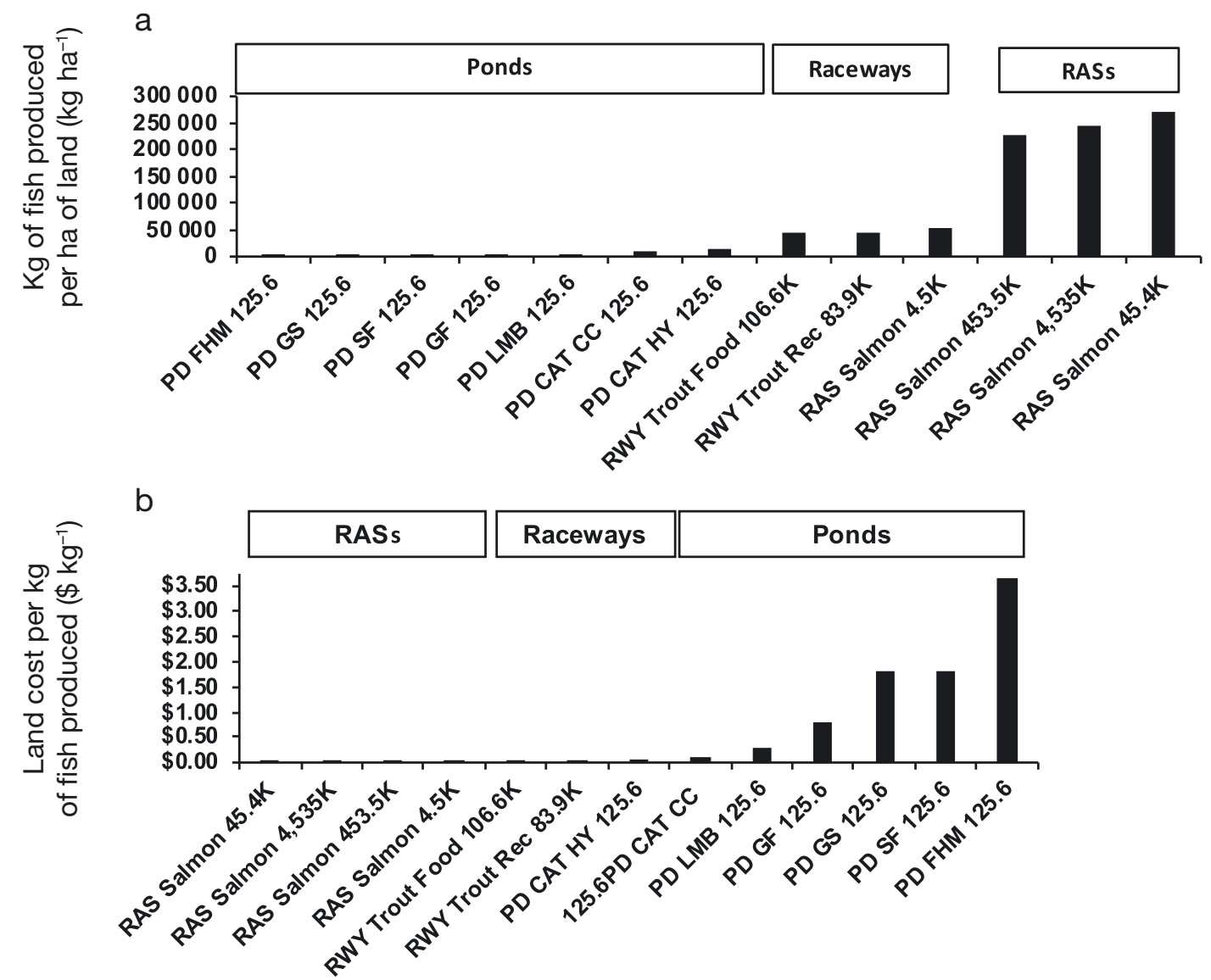

Production/system scale

Fig. 1. (a) Productivity of land use and (b) land cost across production systems. In scenarios where production scale did not affect relative rankings, only one production scale is presented. PD: pond; RWY: raceway; RAS: recirculating aquaculture system; FHM: fathead minnows; GS: golden shiners; SF: sportfish; GF: goldfish; LMB: largemouth bass; CAT CC: channel catfish multiple batch; CAT HY: hybrid catfish intensive aeration; 125.6: pond ha; Trout Food: trout raised for foodfish; Trout Rec: trout raised for recreational market; $106.6 \mathrm{~K}: 106600 \mathrm{~kg}$ produced $\mathrm{yr}^{-1} ; 83.9 \mathrm{~K}$ : $83900 \mathrm{~kg}$ produced $\mathrm{yr}^{-1} ; \mathrm{RAS} 4.5 \mathrm{~K}=4500 \mathrm{~kg}$ pro-

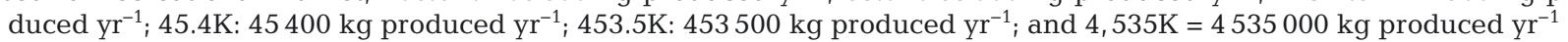

shiners, sportfish, goldfish, largemouth bass for foodfish, multiple-batch production of channel catfish, hybrid catfish production with intensive aeration, and trout raceway production. The lowest land cost per $\mathrm{kg}$ of fish produced was that of RAS production.

\subsection{Water}

The farm scenario that demonstrated the greatest water-use efficiency was that of intensively aerated hybrid catfish production (Fig. 2a), followed by RAS tilapia (45 $400 \mathrm{~kg} \mathrm{yr}^{-1}$ ), multiple-batch channel catfish, the other RAS scenarios, largemouth bass in ponds, and the other pond species. The lowest amount of $\mathrm{kg}$ of fish produced per liter of water was that of raceway production of trout. It should be noted, however, that trout raceway production is not considered to be a 'consumptive' use of water. Water flows through trout raceways and is returned quickly to its original source (Boyd 2005, Tucker \& Hargreaves 2008). Overall, the $\mathrm{kg}$ of fish produced per liter of water from intensively aerated hybrid catfish production was 1.6 times greater than that of multiplebatch catfish production, 2.5 times greater than the average in RAS, 5.0 times greater than largemouth bass produced for foodfish, 29 times greater than the average of other fish production in ponds, and 493 times greater than that of trout raceway production.

The cost of water per $\mathrm{kg}$ of fish produced was greatest for those farm scenarios with the lowest productivity ( $\mathrm{kg}$ of fish per liter of water) except for trout produced in raceways (Fig. 2b). Trout produced in raceways utilize the natural, gravity-driven flow of water from water sources with very little cost for pumping and typically without aeration. Thus, the 


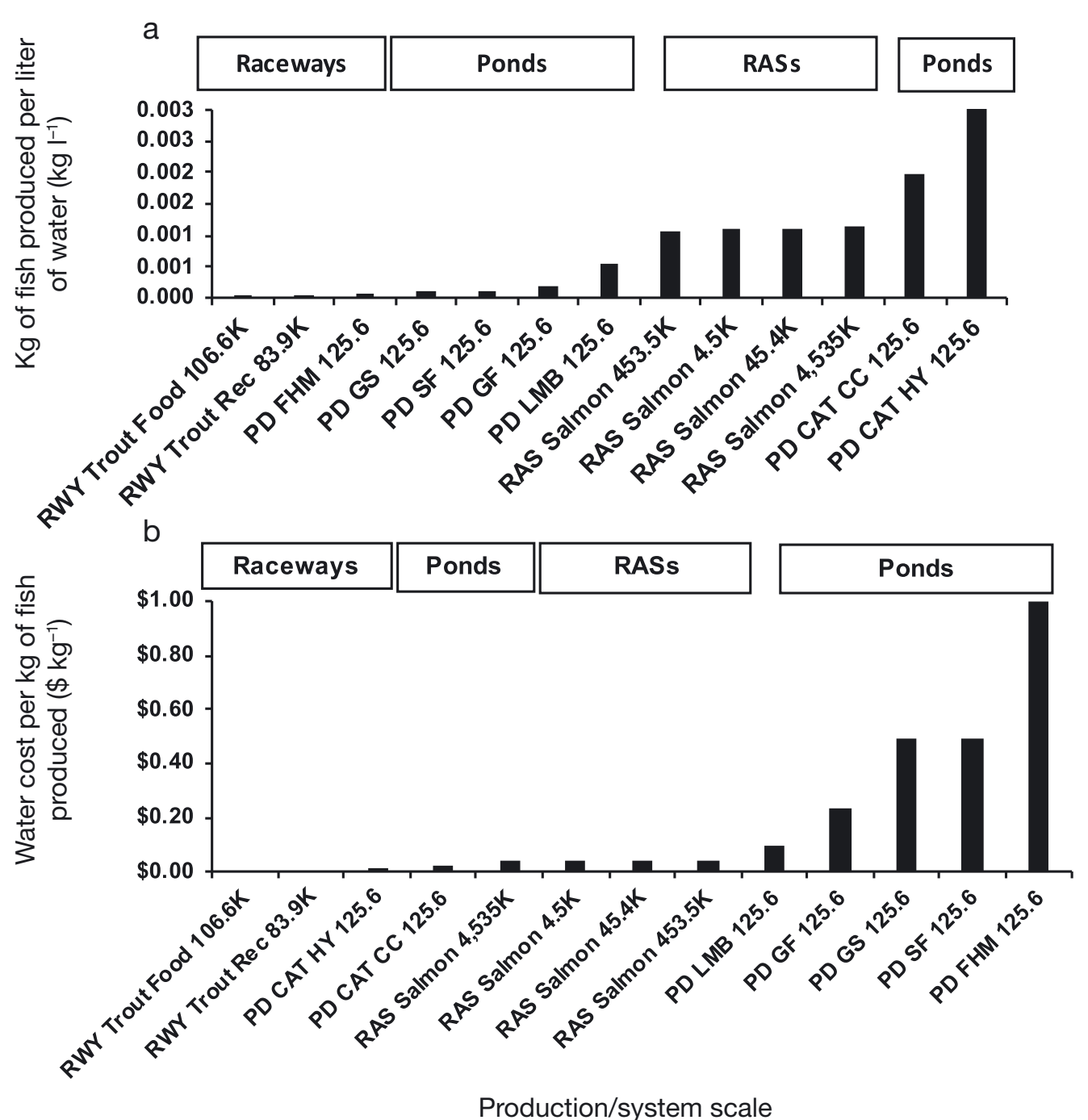

Fig. 2. (a) Water productivity and (b) water cost across production systems. In scenarios where production scale did not affect relative rankings, only one production scale is presented. Abbreviations as in Fig. 1

water cost per $\mathrm{kg}$ of fish produced was lowest for trout despite its overall low value in terms of $\mathrm{kg}$ of fish produced per liter of water returned to the stream. Overall, the water-cost efficiency was lowest for fathead minnows, followed by sportfish and golden shiners, goldfish, largemouth bass produced for foodfish, the RAS systems, and then hybrid catfish with intensive aeration.

\subsection{Feed}

Feed conversion ratios were greatest for the sportfish, largemouth bass for foodfish, and minnow farms (Fig. 3a). Feed conversion ratios for catfish were intermediate, while those of RASs and trout raised in raceways were the lowest. The feed cost per $\mathrm{kg}$ of fish sold was greatest for largemouth bass for foodfish, sportfish, and minnow farms, and lowest in RASs and trout raised in raceways (Fig. 3b). Feed prices in this analysis were not standardized, however, because feed prices vary across species due to different nutritional requirements and costs of ingredients. As a result, the feed-cost efficiencies calculated were affected by varying feed prices for different species.

\subsection{Energy}

The farm scenarios with the most efficient energy use were the 2 catfish scenarios, hybrid catfish with intensive aeration and multiple-batch channel catfish (Fig. 4a). These were followed by trout in raceways and largemouth bass pond production, and then RASs 


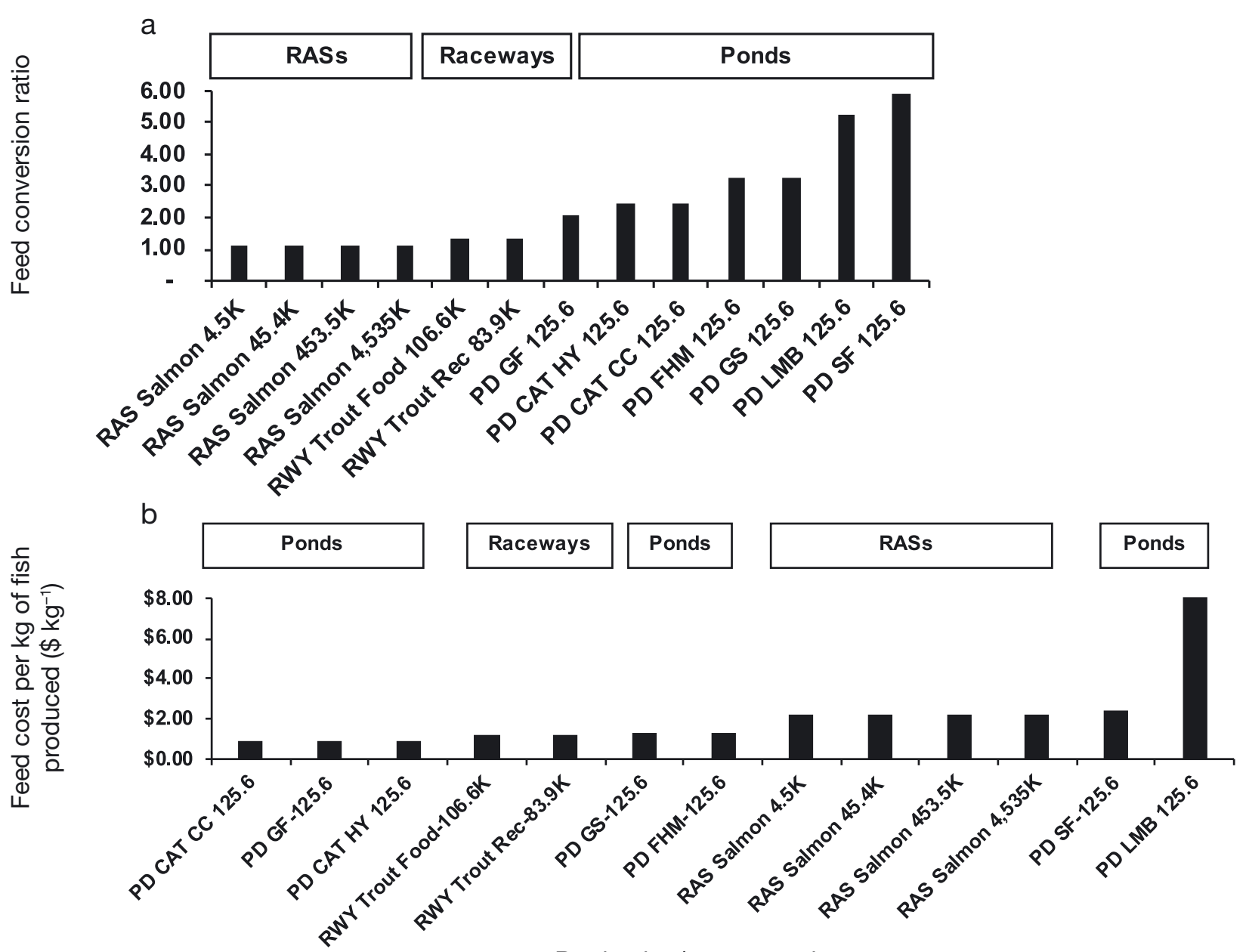

Production/system scale

Fig. 3. (a) Feed conversion ratio and (b) feed cost across production systems. In scenarios where production scale did not affect relative rankings, only 1 production scale is presented. Abbreviations as in Fig. 1

and the other pond-based farm scenarios. The $\mathrm{kg}$ of fish produced per GJ of energy for the hybrid catfish scenario were, on average, $1.2,3.3,4.7,13.1$, and 33.8 times greater than the multiple-batch channel catfish, largemouth bass foodfish, trout in raceways, RASs, and the other pond scenarios, respectively.

The energy cost per $\mathrm{kg}$ of fish produced was greatest for pond production of goldfish, sportfish, fathead minnows, and golden shiner scenarios, followed by RASs, trout in raceways, largemouth bass foodfish, and multiple-batch channel catfish (Fig. 4b). The lowest energy cost per $\mathrm{kg}$ of fish was that of hybrid catfish with intensive aeration.

\subsection{Labor and management}

The 2 catfish scenarios demonstrated by far the greatest labor productivity, as measured in $\mathrm{kg}$ of fish sold per FTE of labor (Fig. 5a). The catfish scenarios were followed by the largest raceway trout foodfish scenario, the $453.5 \mathrm{~kg}$ RAS tilapia scenario, and then the 3 farm scales of largemouth bass. The largest RAS scenarios followed in descending order of labor productivity, followed by the other trout raceway scenarios, the larger goldfish farms, the 45.4K RAS scenarios, and the remaining pond and RAS scenarios. The intensively aerated catfish scenario was 1.3 times more productive in its use of labor than the channel catfish multiple-batch scenario, 7 times more productive than the largemouth bass for foodfish and trout raceway production, 13 times more productive than RAS on average, and 47 times more productive on average than the other pond systems. The larger RAS scenarios showed labor productivity values 6-7 times greater than those of the smallest RAS scenario. The second-largest RAS showed somewhat greater labor productivity values than the 

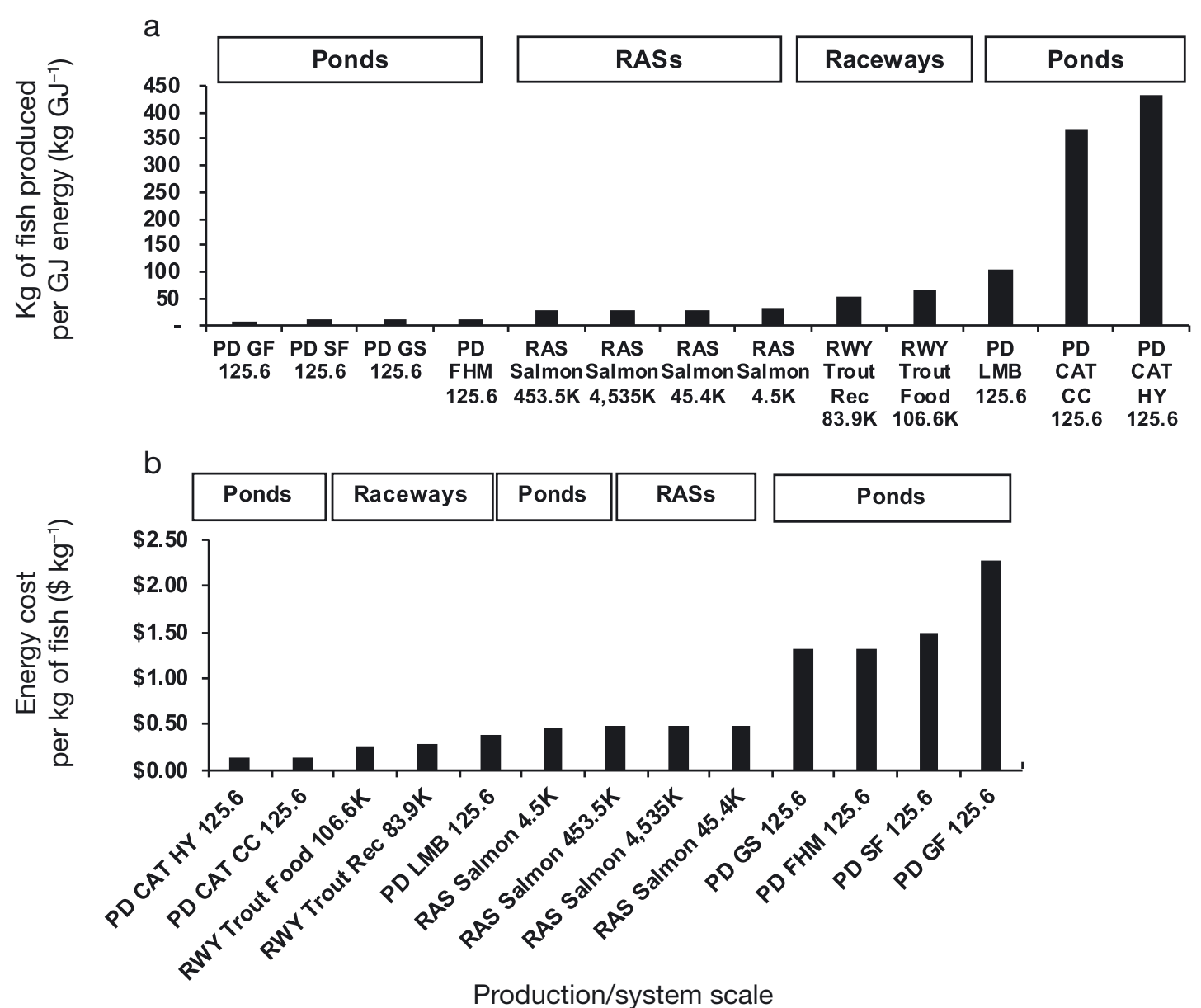

Fig. 4. (a) Energy productivity and (b) energy cost across production systems. In scenarios where production scale did not affect relative rankings, only one production scale was presented. Abbreviations as in Fig. 1

largest RAS. For the pond-based scenarios, larger farms tended to show greater labor productivity than did smaller farms.

Given that labor wages and costs were standardized across the production scenarios analyzed, the labor costs per kg of fish sold showed that the farm scenarios with the lowest labor productivity values had the greatest labor costs per kg of fish sold (Fig. 5b). The greatest labor costs per $\mathrm{kg}$ of fish were those of the smaller pond scenarios raising minnows and sportfish, then the smaller RAS scenarios. The lowest labor cost per $\mathrm{kg}$ was that of the 2 catfish farm scenarios followed by the largest trout foodfish farm scenario. The labor productivity and labor-cost efficiency metrics appear to imply that labor on US aquaculture farms has become more of a fixed rather than a variable cost.

Management productivity was 12 times greater for the 2 averaged catfish scenarios as compared to the average of the other scenarios analyzed (Fig. 6a). The larger farm sizes of largemouth bass produced for foodfish and goldfish followed and then the larger
RAS size scenarios followed. The management cost per kg of fish sold was greatest in the smaller minnow pond scenario and the various smaller RAS scenarios. The lowest management cost per $\mathrm{kg}$ of fish sold was in the 2 catfish farm scenarios, followed by the larger largemouth bass for foodfish and goldfish pond farms, followed by the largest raceway trout foodfish farm and the larger RAS scenarios (Fig. 6b).

\subsection{Capital}

Capital-use efficiency was substantially greater in the 2 catfish farm scenarios as compared to the other scenarios, followed by the largemouth bass foodfish and trout raceway scenarios (Fig. 7a). The larger RAS scenarios followed, inter-mixed with the larger goldfish scenarios. The lowest capital use efficiency values were those of the smaller pond and RAS scenarios. Fig. $7 \mathrm{~b}$ shows the corresponding rankings of the capital cost efficiency, with those scenarios exhibit- 

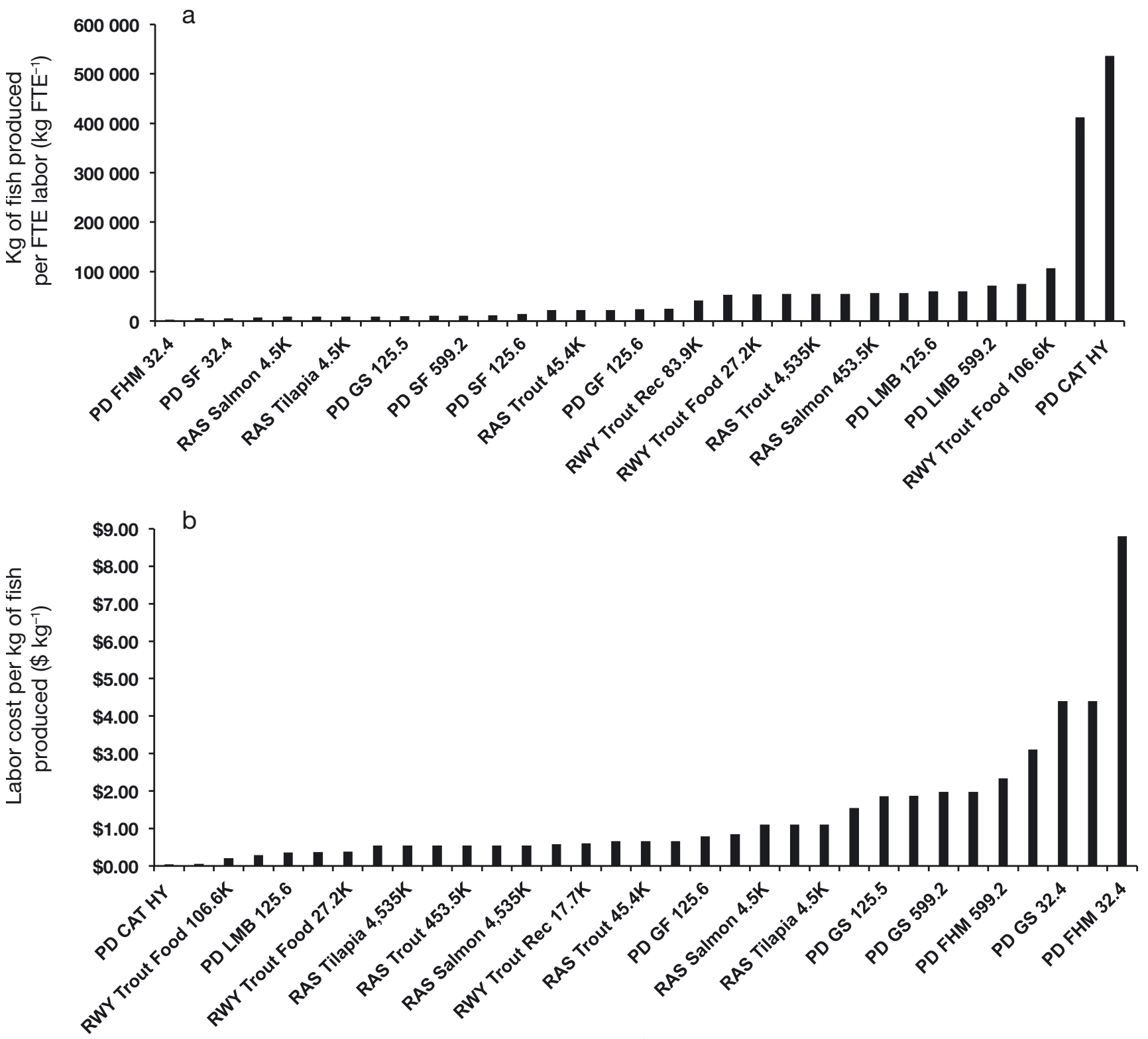

Production system/scale scenario

Fig. 5. (a) Labor productivity and (b) land cost across production systems. Pond-based farm sizes: 32, 124, and 592 ha; Trout raceway production scales were $27.2 \mathrm{~K}, 106.6 \mathrm{~K}, 17.7 \mathrm{~K}, 83.9 \mathrm{~K}$ : production levels of $27200,106600,17700$, and $83900 \mathrm{~kg}^{\mathrm{y}} \mathrm{r}^{-1}$ );

FTE: full-time equivalent; other abbreviations as in Fig. 1

ing the lowest capital use efficiencies (the smaller production scales, pond, and RAS) showing the greatest capital costs per $\mathrm{kg}$ of fish sold. The 2 catfish scenarios showed the lowest capital cost per $\mathrm{kg}$ of fish sold.

\section{DISCUSSION}

Sustainable food production from responsibly managed $^{\underline{8}}$ farms is widely recognized as a necessity. A robust literature has developed on issues related to sustainable aquaculture production. LCA and emergy modeling based on generic assumptions and choice of coefficients for key variables used demonstrate wide variability in results that indicate a low degree of precision (ISO 2006, Henriksson et al. 2012) and fail to account for farm-to-farm variability in terms

\footnotetext{
$\underline{\mathbf{s}}$ For more details on the concept of responsible management of businesses, see UNEP (2012)
} 


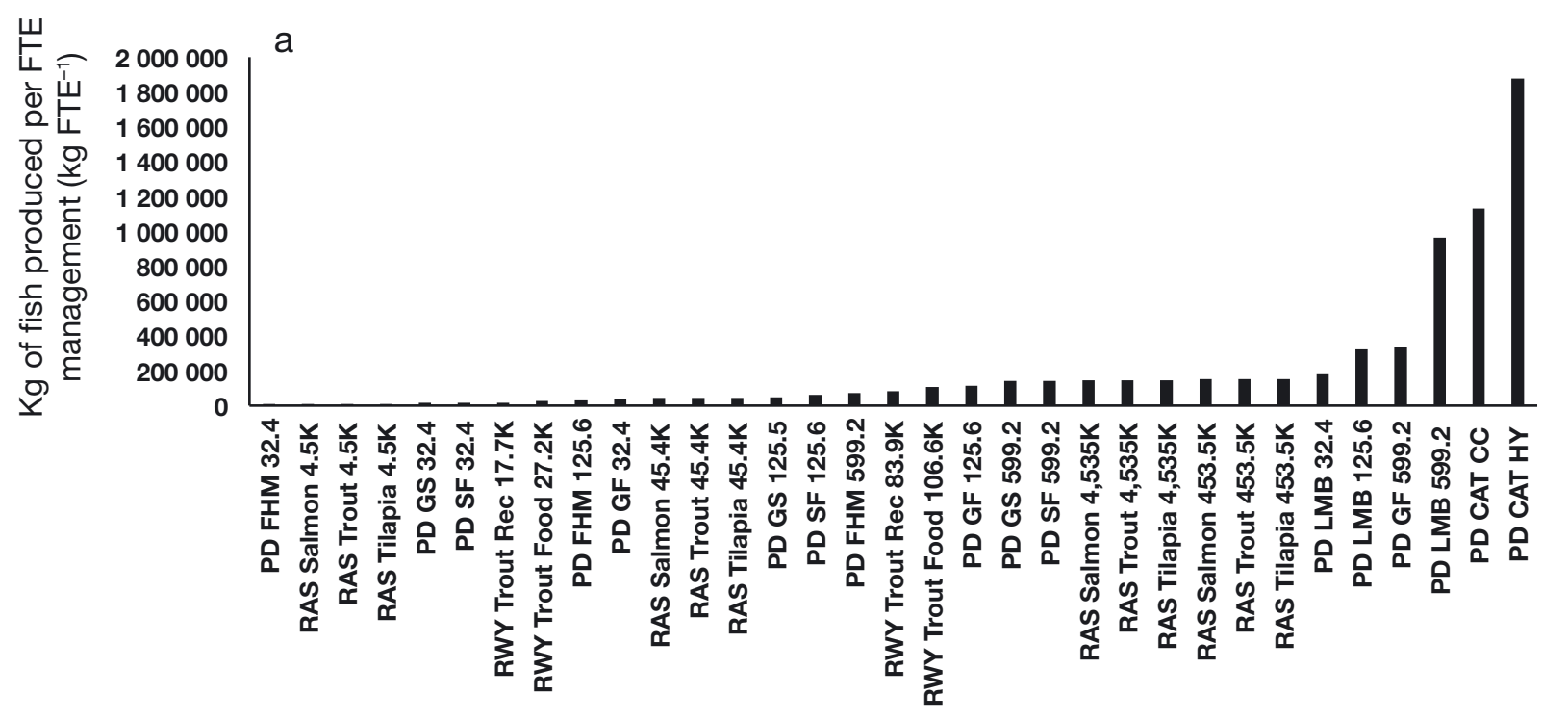

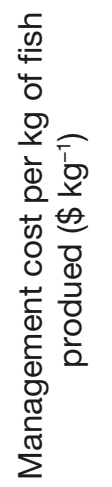

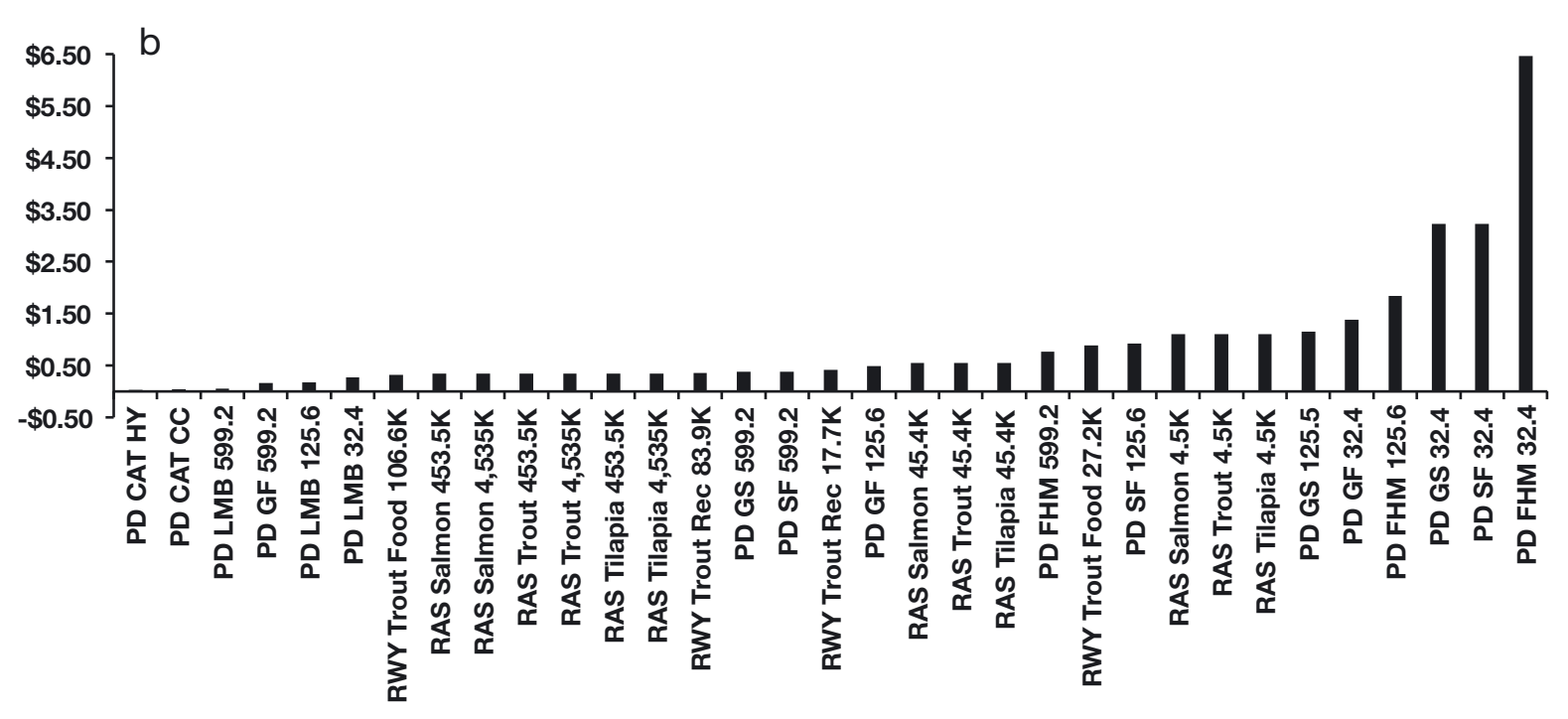

Production system/scale scenario

Fig. 6. (a) Management productivity and (b) management cost across production systems. Abbreviations as in Figs. 1 \& 5

of key aspects of sustainability. While studies have emerged more recently that have measured resourceuse efficiency on farms (Boyd et al. 2017, 2018, Valenti et al. 2018), many of the calculations required would be difficult to implement on farms as an on-going monitoring tool. Yet it is at the level of individual farmers where choices are made as to how aquatic animals will be raised, the level of resources required, and the degree of efficiency of their use. Efficiency metrics are important measures of the amount of resources required to produce a $\mathrm{kg}$ of product (Engle 2010, 2019a). More efficient production processes use fewer resources per $\mathrm{kg}$ of product, are more sustainable, and are more cost efficient (lower cost per $\mathrm{kg}$ of product).
The approach used in this study was to calculate efficiency metrics of resource use per $\mathrm{kg}$ in terms of quantities of resources required and the resulting cost per kg farm record information. Thus, the values used were real-world, not estimated values subject to various types of assumptions and uncertainties. As expected, the cost per $\mathrm{kg}$ metrics calculated generally mirrored (inversely) the quantities of resources used per kg. This was true for land, energy, labor, management, and investment capital. Exceptions to this were found with regard to water and feed use. The exceptions highlight the importance of analyzing sustainability at the farm level, where decisions are made. Despite a few exceptions, cost-efficiency metrics could be used interchangeably with resource- 

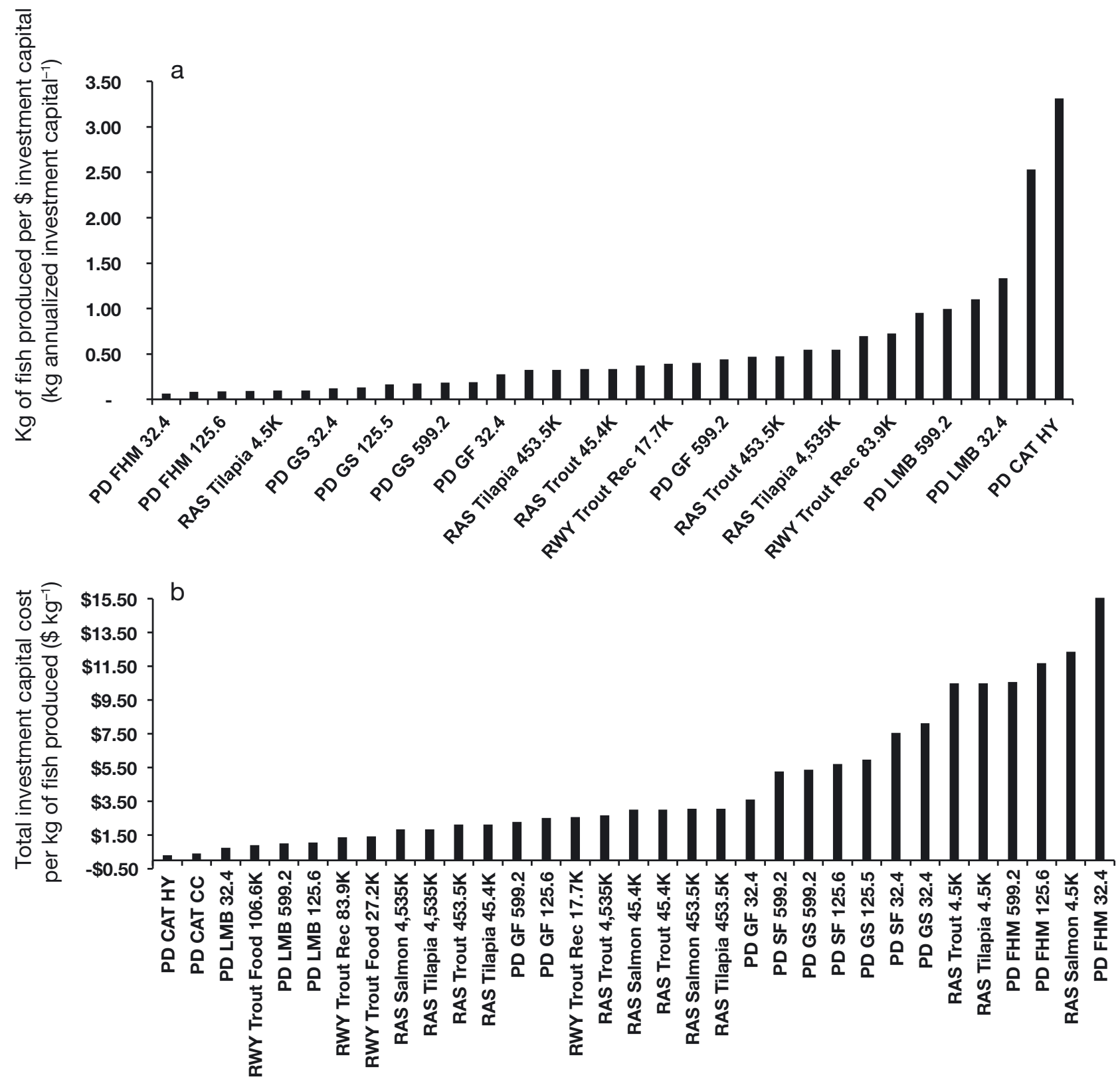

\section{Production system/scale scenario}

Fig. 7. (a) Investment capital and (b) investment capital cost efficiency across production systems. Abbreviations as in Figs. 1 \& 5

use efficiency in terms of discussions related to the relative sustainability of aquaculture production systems.

With water use, the same relationship between cost efficiency and resource-use efficiency was found among all scenarios except for trout production in raceways. Trout produced in raceways rely on flowthrough of water that results in a greater water use footprint (in terms of liters of water per $\mathrm{kg}$ of trout production) than pond and RAS production. Since there is little cost associated with use of gravity-flow water, the cost per $\mathrm{kg}$ is low despite the total water volume. The large volume of water that moves through raceways is not 'consumed' ${ }^{\mathbf{9}}$ in trout production but in most cases is promptly returned to the original water source at the same quality owing to strict regulatory discharge requirements in the USA (Boyd 2005, Tucker \& Hargreaves 2008), where trout farms have been required for decades to conduct routine sampling and testing of discharge water to

$\underline{9}$ 'Consumption' of water is defined in these studies as the sum of the reduction in stream flow and the volume of water withdrawn from wells 
maintain state-enforced permits for discharge. It should also be noted that most US trout farms have quiescent zones as a separate cell in the raceways from which sludge is vacuumed into an offline settling basin prior to discharge to the receiving stream. Tucker \& Hargreaves (2008) contrasted total water use with consumptive water use among production systems, concluding that $100 \%$ of water use in RAS is consumptive, as compared to $46 \%$ in static catfish ponds, and less than $1 \%$ in trout produced in raceways. The metrics presented in the present study did not account for or adjust for total water requirements as opposed to water 'consumed', nor consider the value of water in areas in which scarcity has created markets for use of scarce water resources. Monitoring water use on any type of farm is the first step in the search for ways to reduce water volumes used, particularly in those systems that previous research has shown to 'consume' greater quantities of water, as in RASs. For example, detailed studies of water use on US catfish farms led to the 'drop-fill' method to capture maximum amounts of rainwater to replace evaporative losses and reduce groundwater pumping (Tucker et al. 2017).

Feed use was the second exception to the close relationship between physical efficiencies (quantity of resource used per $\mathrm{kg}$ of aquatic animal product) and cost efficiencies (resource cost per $\mathrm{kg}$ of production). Feed costs used in this study were not standardized across species because differing feed formulations required for nutritionally complete feeds result in a wide range of feed prices. This analysis used standard diets used for each species and the associated average commercial cost. Feed for largemouth bass, for example, is more expensive than feed fed to catfish, given the respective differences in nutritional requirements. Feed costs used in the analysis were based on nutritionally complete commercial feeds formulated for each species that correspond to the yields, feed conversion ratio, and other key production parameters reported for each species. The varying feed costs resulted in different rankings of the various species based on whether physical ( $\mathrm{kg}$ feed per kg of fish) or cost efficiency (feed cost per $\mathrm{kg}$ of fish) metrics were used. This is yet another example of the importance of including sufficiently detailed farm data in analyses to account for critical, but realistic, differences in outcomes at the farm level.

Results of this analysis highlight the importance of examining resource-use efficiencies of key resources when discussing relative sustainability. Different production systems in this study demonstrated varying levels of efficiency for the resources analyzed. For example, RASs were relatively more efficient in terms of land use than were raceway or pond production, whereas the intensive pond scenarios of catfish production made more efficient use of water, energy, labor, management, and capital resources (Table 3). While the focus of this study was not on embodied use of energy in feed or capital assets such as tanks, ponds, or equipment (Boyd et al. 2017, 2018, Chatvijitkul et al. 2017a), farms that used feed, energy, water, and capital more efficiently were found to also use less energy overall than those that used those inputs less efficiently.

The pond scenarios analyzed included a wide range of levels of efficiency, and the results support conclusions of other studies that intensification of aquaculture production results in increased sustainability of use of land and water resources (Bosma \& Verdegem 2011, Boyd et al. 2017, 2018, Engle et al. 2017). From

Table 3. Comparison of resource use and resource cost efficiencies by production system. RAS: recirculating aquaculture system; FCR: feed conversion ratio; FTE: full-time equivalent

\begin{tabular}{|c|c|c|c|c|c|}
\hline Resource metric & Catfish & $\begin{array}{c}\text { Ponds } \\
\text { Large- } \\
\text { mouth bass }\end{array}$ & $\begin{array}{l}\text { Minnows/ } \\
\text { sportfish }\end{array}$ & $\begin{array}{c}\text { Raceways } \\
\text { Trout }\end{array}$ & $\begin{array}{c}\text { RASs } \\
\text { Salmon, } \\
\text { trout, } \\
\text { tilapia }\end{array}$ \\
\hline \multicolumn{6}{|l|}{ Land } \\
\hline $\mathrm{kg} \mathrm{ha}^{-1}$ & 10656 & 3568 & 514 & 44807 & 199920 \\
\hline$\$$ land $\mathrm{kg}^{-1}$ fish & 0.08 & 0.23 & 2.02 & 0.02 & 0.01 \\
\hline \multicolumn{6}{|l|}{ Water } \\
\hline $\mathrm{kg} \mathrm{l}^{-1}$ & 0.00262 & 0.00066 & 0.00011 & 0.00001 & 0.00132 \\
\hline$\$$ water $\mathrm{kg}^{-1}$ fish & 0.02 & 0.08 & 0.56 & 0.00 & 0.04 \\
\hline \multicolumn{6}{|l|}{ Feed } \\
\hline FCR & 2.45 & 4.48 & 3.64 & 1.30 & 1.34 \\
\hline$\$$ feed $\mathrm{kg}^{-1}$ fish & 0.87 & 6.91 & 1.49 & 1.22 & 1.61 \\
\hline \multicolumn{6}{|l|}{ Energy } \\
\hline $\mathrm{kg}$ fish $\mathrm{GJ}^{-1}$ energy & 401 & 130 & 12 & 92 & 33 \\
\hline$\$$ energy $\mathrm{kg}^{-1}$ fish & 0.14 & 0.33 & 1.60 & 0.28 & 0.43 \\
\hline \multicolumn{6}{|l|}{ Labor } \\
\hline kg fish $\mathrm{FTE}^{-1}$ & 473966 & 63940 & 11366 & 64136 & 37510 \\
\hline$\$$ labor $\mathrm{kg}^{-1}$ fish & 0.05 & 0.34 & 2.83 & 0.44 & 0.71 \\
\hline \multicolumn{6}{|l|}{ Management } \\
\hline $\mathrm{kg}_{\text {fish FTE }} \mathrm{FT}^{-1}$ & 1504545 & 489872 & 84846 & 58844 & 87972 \\
\hline$\$$ mgmt $\mathrm{kg}^{-1}$ fish & 0.04 & 0.17 & 1.70 & 0.49 & 0.58 \\
\hline \multicolumn{6}{|l|}{ Investment capital } \\
\hline $\mathrm{kg}$ fish per $\$$ inv. cap. & 2.92 & 1.09 & 0.19 & 0.73 & 0.33 \\
\hline$\$$ inv. cap. per kg fish & 0.35 & 0.94 & 7.01 & 1.57 & 3.98 \\
\hline
\end{tabular}


the perspective of economic and financial sustainability, however, more intensive production may not always be more sustainable. For businesses such as baitfish and sportfish production, the determinants of demand for their products differ substantially when compared to demand for other seafood products in the USA. The business models developed for baitfish and sportfish production have evolved to meet the unique demand for those products for which market considerations play a much larger role in successful business models than does yield or land productivity. The longevity of the baitfish and sportfish industries exemplifies the importance of serving market needs and not exclusively focusing on productivity metrics in managing aquaculture businesses. Such less-intensive industries in the USA have tended to be concentrated in areas with abundant (and as a result, less costly) land and water resources.

Aquaculture production technologies continue to evolve rapidly as research continues to identify and develop improved production practices. Therefore, estimates of resource use on farms will continue to change as production practices evolve. For example, previous estimates of water use in catfish production ranged from $1500 \mathrm{~m}^{3} \mathrm{t}^{-1}$ fish (Boyd et al. 2007) to $2000 \mathrm{~m}^{3} \mathrm{t}^{-1}$ (Hargreaves et al. 2002), based on catfish production technologies with average yields of approximately $4000-5000 \mathrm{~kg} \mathrm{ha}^{-1}$ (with approximately $1.8 \mathrm{~kW} \mathrm{ha}^{-1}$ aeration). Recently adopted changes in catfish production methods (Kumar et al. 2018a,b, 2020a) have intensified catfish production such that the 2 most common production practices produce yields of 9000-15000 kg ha- ${ }^{-1}$. These current yields are 2 to 3 times greater than the yields of catfish when previous estimates of water use were made. Water use in this study was $306-456 \mathrm{~m}^{3} \mathrm{t}^{-1}$ of catfish, 3-6 times lower than previous estimates, due to the greater yields of catfish produced per ha (Kumar et al. 2020a).

Water use values calculated for RAS production in this study were greater than those reported elsewhere (Bregnballe 2015, Liu et al. 2016). Total water volume use in a RAS facility in the present study included water use for the hatchery and smolt sections of integrated facilities. Fish brought to the facility must be quarantined in separate tanks with a separate water supply to avoid introduction of disease pathogens. Production-related problems in individual tanks may require unplanned draining and refilling of tanks, and fish raised in RASs must be purged of off-flavors prior to sale (Davidson et al. 2014). Moreover, total water volumes for RASs must also include water required for cleanup functions and general usage on the farm (Timmons 2002), as estimated in this analysis. However, additional work is needed to develop realistic and accurate estimates of total water use measured in commercial RASs.

Various studies have discussed the energy-intensive nature of RASs as well as the variability of energy use across systems (Badiola et al. 2012, 2017, 2018, Bergheim \& Nilsen 2015, Nistad 2020). As in the present study, these energy-use studies of RAS did not account for embodied energy in the capital assets (tanks, filters, pumps) or feed used. One study concluded that RAS production would meet the requirement for 'sustainable intensification' if its carbon footprint would be reduced (Jeffery et al. 2011). It is possible that this may also be true for other species raised in RASs. Badiola et al. (2018) reported energy use that varied from 2.9 to $81.5 \mathrm{kWh} \mathrm{kg}^{-1}$ in RASs. For Atlantic salmon smolt production, Nistad (2020) found on-site energy use of 5.1 to $81.5 \mathrm{kWh} \mathrm{kg}^{-1}$ in RASs and reported energy use for salmon growout to range from 6 to $10 \mathrm{kWh} \mathrm{kg}^{-1}$. Bergheim \& Nilsen (2015) found that smolts used $4.1 \mathrm{kWh} \mathrm{kg}^{-1}$ in Norway, but $20 \mathrm{kWh} \mathrm{kg}^{-1}$ in Canada.

US aquaculture is subject to stringent regulatory requirements and comprehensive enforcement of such requirements (Engle \& Stone 2013). Aquaculture farms that violate laws related to environmental discharges in the USA are not allowed to continue to operate in such a fashion. The enforcement of such stringent compliance measures results in high environmental sustainability of US aquaculture practices. In addition, the strong economic contributions of aquaculture farms to rural communities and economies (Kaliba \& Engle 2004) has further created social acceptance in many (although not all) regions in the USA. In terms of economic sustainability, the scenarios analyzed in this study reflect business realities of segments of US aquaculture that have been economically sustainable for many years. The exception to this is, of course, RASs, for which there are only a few commercial examples of successful RAS businesses. Regions where land and water are less expensive can support more extensive production systems, such as that of minnows and sportfish. Clearly, in regions with very high land values, RASs would be expected to be more competitive economically due to its more efficient use of land. There are some examples of RASs that have been incorporated into overall pond-based farming businesses to allow year-round production of fingerlings or to culture specific species that do not grow well in outdoor ponds. For some business models, the greater costs of RASs may be overshadowed by farm business goals 
to maintain market share, to diversify market revenue with other species, or other business goals (Sapkota et al. 2014). Thus, while some production systems use some resources more efficiently than do others, existing aquaculture businesses in the USA, regardless of species or production system, are managed as sustainable food production systems.

The efficiency of use of labor in aquaculture practices is rarely discussed. Yet, the availability of labor for aquaculture farms has increasingly been mentioned as a growing problem (Engle 2010, 2019a, van Senten \& Engle 2017, Engle et al. 2019, van Senten et al. 2020). Thus, it appears that more attention needs to be paid to relative efficiencies of labor in discussions related to the economic sustainability of aquaculture in the USA and perhaps other countries.

While US aquaculture is practiced in a highly sustainable way, the pressure from continuous population growth requires that resources be used in increasingly efficient ways. Studies of the farm adoption of new practices and technologies show that a key incentive is improved farm profitability (Kumar \& Engle 2017a, Kumar et al. 2018a, 2020b). Thus, encouraging farms to include efficiencies of resource use and cost in their annual review of farm productivity and financial performance would also encourage farms to increase efficiency of resource use as an incentive to reduce production costs. Researchers and Extension specialists could use the metrics assessed in this study as a way to discuss the potential value of new farming practices and technologies to enhance profitability of farming businesses as a component of technology dissemination efforts.

\section{CONCLUSIONS}

A set of practical resource-use efficiency metrics was developed and calculated for a wide range of established finfish farm scenarios using farm-level data. Efficiency metrics were also calculated for RAS production of salmon, trout, and tilapia, but were based on previously published economic analyses due to the lack of sufficient RAS businesses in the USA to preserve the confidentiality of RAS farm data. Metrics calculated based on cost of resources used showed the same efficiency relationships as those based on physical quantities, with a few exceptions.

More intensive production systems were found to use resources (land, water, energy, labor, management, and capital) more efficiently per kg of fish produced than less intensive production systems with lower yields $\left(\mathrm{kg} \mathrm{ha}^{-1}\right)$. Except for land and feed use, however, intensive pond production of catfish resulted in the most efficient use of resources overall, demonstrating the overall highest degree of sustainability of catfish pond production as compared to other systems and species. RAS production was the most efficient in terms of land and feed use among all scenarios evaluated. The metrics used in this analysis were those that can be calculated in a fairly simple fashion on farms. While these metrics do not capture the full effects of embodied energy resources in feed, tanks, equipment, and sources of energy, among others, they offer a practical way for farm owners and managers to monitor resource use as a way to both control costs and improve farm profitability by seeking to use resources in the most efficient manner possible.

Acknowledgements. This work was supported by USDA NIFA grant no. 2016-70007-25757 accession no. 1010733 from the USDA National Institute of Food and Agriculture. Any opinions, findings, conclusions, or recommendations expressed in this publication are those of the authors and do not necessarily reflect the view of the US Department of Agriculture.

\section{LITERATURE CITED}

Aubin J, Papatryphon E, van der Werf HMG, Chatzifotis S (2009) Assessment of the environmental impact of carnivorous finfish production systems using life cycle assessment. J Clean Prod 17:354-361

* Badiola M, Mendiola D, Bostock J (2012) Recirculating aquaculture systems (RAS) analysis: main issues on management and future challenges. Aquac Eng 51:26-35

* Badiola M, Basurko O, Gabiña G, Mendiola D (2017) Integration of energy audits in the life cycle assessment methodology to improve the environmental performance assessment of recirculating aquaculture systems. J Clean Prod 157:155-166

* Badiola M, Basurko O, Piedrahita R, Hundley P, Mendiola D (2018) Energy use in recirculating aquaculture systems (RAS): a review. Aquac Eng 81:57-70

Barry P, Ellinger P (2012) Fundamental management in agriculture, $7^{\text {th }}$ edn. Prentice Hall Publishing, Upper Saddle River, NJ

* Bergheim A, Nilsen A (2015) Intensification of salmonid aquaculture. ATINER'S Conference Paper Series No. WAT2015-1652. ATINER, Athens. https://www.atiner.gr/ papers/WAT2015-1652.pdf

Bjorndal T, Tusvik A (2017) Land-based farming: economic analysis. Working Paper Series No. 1/2017. Department of International Business, Norwegian University of Science and Technology, Ålesund

Bjorndal T, Tusvik A (2019) Economic analysis of land based farming of salmon. Aquac Econ Manag 23:449-475

* Bosma R, Verdegem M (2011) Sustainable aquaculture in ponds: principles, practices and limits. Livest Sci 139: 58-68

Boulet D, Struthers A, Gilbert E (2010) Feasibility study of closed-containment options for the British Columbia 
aquaculture industry. Innovation and Sector Strategies, Aquaculture Management Directorate, Fisheries and Oceans Canada, Vancouver

Boyd CE (1987) Water conservation measures in fish farming. In: Fifth conference on applied climatology. American Meteorological Society, Boston, MA, p 88-91

Boyd CE (2005) Water use in aquaculture. World Aquac 36: $12-13$

Boyd CE, McNevin A (2015) Aquaculture, resource use, and the environment. Wiley-Blackwell, Hoboken, NJ

Boyd CE, Tucker C, McNevin A, Bostick K, Clay J (2007) Indicators of resource use efficiency and environmental performance in fish and crustacean aquaculture. Rev Fish Sci 15:327-360

Boyd CE, McNevin AA, Racine P, Tinh HQ and others (2017) Resource use assessment of shrimp, Litopenaeus vannamei and Penaeus monodon, production in Thailand and Vietnam. J World Aquacult Soc 48:201-226

Boyd CE, McNevin A, Davis RP, Godumala R, Mohan ABCh (2018) Production methods and resource use at Litopenaeus vannamei and Penaeus monodon farms in India compared with previous findings from Thailand and Vietnam. J World Aquacult Soc 49:551-569

Boyd CE, D'Abramo LD, Glencross BD, Huyben DC and others (2020) Achieving sustainable aquaculture: historical and current perspectives. J World Aquacult Soc 51: 578-633

Bregnballe J (2015) A guide to recirculation aquaculture. FAO and EUROFISH International Organisation. http:// www.fao.org/3/i4626e/i4626e.pdf

Brown MT, Herendeen RA (1996) Embodied energy analysis and EMERGY analysis: a comparative view. Ecol Econ 19:219-235

Cao L, Diana JS, Keoleian GA, Lai Q (2011) Life cycle assessment of Chinese shrimp farming systems targeted for export and domestic sales. Environ Sci Technol 45: 6531-6538

Cao L, Diana JS, Keoleian GA (2013) Role of life cycle assessment in sustainable aquaculture. Rev Aquacult 5:61-71

Chatvijitkul S, Boyd CE, Davis DA, McNevin AA (2017a) Embodied resources in fish and shrimp feeds. J World Aquacult Soc 48:7-19

Chatvijitkul S, Boyd CE, Davis DA, McNevin AA (2017b) Pollution potential indications for feed-based fish and shrimp culture. Aquaculture 477:43-49

Cleveland B, Summerfelt S (2016) What size to harvest rainbow trout and steelhead in recirculating aquaculture systems? Aquaculture Innovation Workshop, Roanoke, VA

Costa-Pierce BA (2010) Sustainable ecological aquaculture systems: the need for a new social contract for aquaculture development. Mar Technol Soc J 44:88-112

* Crouse C, Davidson J, Good C, May T, Summerfelt S, Kenney PB, Cleveland BM (2018) Growth and fillet quality attributes of five genetic strains of rainbow trout reared in a partial water reuse system and harvested at different sizes. Aquacult Res 49:1672-1681

Davidson J, Schrader K, Ruan E, Swift B and others (2014) Evaluation of depuration procedures to mitigate the offflavor compounds geosmin and 2-methylisoborneol from Atlantic salmon Salmo salar raised to market-size in recirculating aquaculture systems. Aquac Eng 61:27-34

Engle CR (2010) Aquaculture economics and financing: management and analysis. Blackwell Scientific, Ames, IA

Engle CR (2019a) Aquaculture businesses: a practical guide to economics and marketing. 5m Publishing, Sheffield
Engle CR (2019b) Economics. In: Tidwell J, Coyle S (eds) Largemouth bass aquaculture. 5m Publishing, Sheffield

Engle CR (2019c) Bringing aquaculture sustainability down to earth. J World Aquacult Soc 50:246-248

*Engle CR, D'Abramo L (2016) Showcasing research focusing on sustainability of aquaculture enterprises and global food security. J World Aquacult Soc 47:311-313

Engle CR, Stone NM (2013) Competitiveness of US aquaculture within the current US regulatory framework. Aquac Econ Manag 17:251-280

Engle CR, McNevin AA, Racine P, Boyd CE and others (2017) Economics of sustainable intensification of aquaculture: evidence from shrimp farms in Vietnam and Thailand. J World Aquacult Soc 48:227-239

Engle CR, van Senten J, Fornshell G (2019) Regulatory costs on US salmonid farms. J World Aquacult Soc 50:522-549

* Engle CR, Kumar G, van Senten J (2020) Cost drivers and profitability of US pond, raceway, and RAS aquaculture. J World Aquacult Soc 51:847-873

FAO (1999) Indicators for sustainable development of marine capture fisheries. FAO Technical Guidelines for Responsible Fisheries No. 8. FAO, Rome

FAO (2011) Indicators for the sustainable development of finfish Mediterranean aquaculture: highlights from the dam project. General Fisheries Commission for the Mediterranean Studies and Reviews No. 90. FAO, Rome

*Good C, Davidson J, Welsh C, Snekvik K, Summerfelt S (2010) The effects of carbon dioxide on performance and histopathology of rainbow trout Oncorhynchus mykiss in water recirculation aquaculture systems. Aquac Eng 42: 51-56

Hargreaves JA, Boyd CE, Tucker CS (2002) Water budgets for aquaculture production. In: Tomasso JR (ed) (2002) Aquaculture and the environment in the United States. US Aquaculture Society, World Aquaculture Society, Baton Rouge, LA, p 9-34

*Henriksson PJG, Guinée JB, Kleijn R, de Snoo GR (2012) Life cycle assessment of aquaculture systems - a review of methodologies. Int J Life Cycle Assess 17:304-313

*Henriksson PJG, Rico A, Zhang W, Ahmad-Al-Nahid S and others (2015) Comparison of Asian aquaculture products by use of statistically supported life cycle. Environ Sci Technol 49:14176-14183

* Hilborn R, Banobi J, Hall SJ, Pucylowski T, Walsworth TE (2018) The environmental cost of animal source foods. Front Ecol Environ 16:329-335

Hinshaw J, Rogers LE, Easley JE (1990) Budgets for trout production: estimated costs and returns for trout farming in the South. SRAC Publication 221. Southern Regional Aquaculture Center, Mississippi State University, Stoneville, MS

Hinshaw J, Engle CR, van Senten J (in press) Enterprise budgets for trout production. SRAC Fact Sheet. Southern Regional Aquaculture Center, Mississippi State University, Stoneville, MS

ISO (2006) ISO 14044:2006. Environmental managementlife cycle assessment-requirements and guidelines. International Organization for Standardization, Geneva

Jeffery K, Stinton N, Ellis T (2011) A review of the landbased, warm-water recirculation fish farm sector in England and Wales. FES220. Centre for Environment, Fisheries \& Aquaculture Science, Lowestoft

Jonell M, Henriksson PJG (2015) Mangrove-shrimp farms in Vietnam - comparing organic and conventional systems using life cycle assessment. Aquaculture 447:66-75 
Kaliba AR, Engle CR (2004) The economic impact of the catfish, Ictalurus punctatus, industry on Chicot County, Arkansas. J Appl Aquac 15:29-60

Kay R, Edwards W, Duffy P (2012) Farm management, $7^{\text {th }}$ edn. McGraw-Hill Publishing. New York, NY

Kumar G, Engle C (2017a) Optimal investment pathways for new catfish production technologies: a recursive programming approach. Aquac Econ Manag 21:144-162

Kumar G, Engle C (2017b) Economics of intensively aerated catfish ponds. J World Aquacult Soc 47:416-429

Kumar G, Tucker C, Engle C (2016) Economics of split-pond systems. J World Aquacult Soc 47:327-340

Kumar G, Engle C, Tucker C (2018a) Factors driving aquaculture technology adoption. J World Aquacult Soc 49: 447-476

Kumar G, Engle CR, Hanson TR, Tucker CS and others (2018b) Economics of alternative catfish production practices. J World Aquacult Soc 49:1039-1057

Kumar G, Engle C, Hegde S, van Senten J (2020a) Economics of US catfish farming practices: profitability, economies of size, and liquidity. J World Aquacult Soc 51:829-846

Kumar G, Engle C, Avery J, Dorman L, Whitis G, Roy LA, Xie L (2020b) Characteristics of early adoption and nonadoption of alternative catfish production technologies in the US. Aquac Econ Manag 25:70-88

Lazard J, Rey-Valette H, Aubin J, Mathé S and others (2014) Assessing aquaculture sustainability: a comparative methodology. Int J Sustain Dev World Ecol 21: 503-511

Liu Y, Rosten TW, Henriksen K, Hognesa E, Summerfelt S, Vinci B (2016) Comparative economic performance and carbon footprint of two farming models for producing Atlantic salmon (Salmo salar): land-based closed containment system in freshwater and open net pen in seawater. Aquac Eng 71:1-12

Nistad AA (2020) Current and future energy use for Atlantic salmon farming in recirculating aquaculture systems in Norway. MSc thesis, Norwegian University of Science and Technology, Trondheim

Osmundsen TC, Amundsen VS, Alexander KA, Asche F and others (2020) The operationalisation of sustainability: sustainable aquaculture production as defined by certification schemes. Glob Environ Change 60:102025

Papatryphon E, Petit J, Kaushik SJ, van der Werf HMG (2004) Environmental impact assessment of salmonid feeds using life cycle assessment (LCA). Ambio 33:316-323

* Pelletier N, Tyedmers P, Sonesson U, Scholz A and others (2009) Not all salmon are created equal: life cycle assessment (LCA) of global salmon farming systems. Environ Sci Technol 43:8730-8736

Philis G, Ziegler F, Gansel LC, Jansen MD, Gracey EO, Stene A (2019) Comparing life cycle assessment (LCA) of salmonid aquaculture production systems: status and perspectives. Sustainability 11: 2517

Samuel-Fitwi B, Wuertz S, Schroeder JP, Schulz C (2012) Sustainability assessment tools to support aquaculture development. J Clean Prod 32:183-192

Editorial responsibility: Louis Lebel,

Chiang Mai, Thailand

Reviewed by: 3 anonymous referees
Sapkota P, Engle CR, Wui P (2014) A mathematical programming model of year-round hybrid striped bass (oMorone chrysops $\times \mathrm{o}^{7}$ Morone saxatilis) fingerling production. Aquac Econ Manag 18:60-75

Seafood Watch (2017) Channel catfish/United States/ponds. Seafood Watch, Monterey Bay Aquarium, Monterey, CA. https://www.seafoodwatch.org/recommendation/catfish/ green-catfish-channel-catfish-united-states-ponds?species $=135$

* Stone N, Kelly A, Roy L (2016) A fish of weedy waters: golden shiner biology and culture. J World Aquacult Soc 47:152-200

Stone N, Roy L, Park E (2019) Fathead minnow reproduction: implications for commercial culture. J World Aquacult Soc 50:267-298

Timmons M (2002). Entrepreneurial and economic issues of recirculating aquaculture ventures. In: Libey GS, Timmons M (eds) (2002) Recirculating aquaculture. Ithaca Publishing Company LLC, Ithaca, NY, p 1-8

Tucker C, Hargreaves J (eds) (2008) Environmental best management practices for aquaculture. Wiley-Blackwell, Ames, IA

Tucker CS, Pote JW, Wax CL, Brown TW (2017) Improving water-use efficiency for ictalurid catfish pond aquaculture in northwest Mississippi, USA. Aquac Res 48: $447-458$

UN (United Nations) (1992) Agenda 21. United Nations Sustainable Development, United Nations Conference on Environment \& Development. United Nations, New York, NY

UNEP (United Nations Environment Program) (2012) Responsible resource management for a sustainable world: findings from the International Resource Panel. United Nations Environment Program, Paris

USDA-NASS (2018) Land values: 2018 summary. National Agricultural Statistics Service, United States Department of Agriculture, Washington, DC

USDA-NASS (2019) Census of aquaculture (2018). National Agricultural Statistics Service, United States Department of Agriculture, Washington, DC

UUSEIA (US Energy Information Administration) (2020) US all grades all formulations retail gasoline prices (dollars per gallon). www.eia.gov/dnav/pet/hist/LeafHandler. $\mathrm{ash} x ? \mathrm{n}=\mathrm{PET} \& \mathrm{~s}=\mathrm{EMM}$ EPM0_PTE_NUS_DPG\&f=M

*Valenti WC, Kimpara JM, Preto BL, Moraes-Valenti P (2018) Indicators of sustainability to assess aquaculture systems. Ecol Indic 88:402-413

*van Senten J, Engle CR (2017) The costs of regulations on US baitfish and sportfish producers. J World Aquacult Soc 48:503-517

van Senten J, Engle CR, Hudson B, Conte FS (2020) Regulatory costs on Pacific coast shellfish farms. Aquacult Econ Manag 24:447-479

Y Yacout DM, Soliman NF, Yacout MM (2016) Comparative life cycle assessment (LCA) of tilapia in two production systems: semi-intensive and intensive. Int J Life Cycle Assess 21:806-819

Submitted: December 14, 2020

Accepted: May 7, 2021

Proofs received from author(s): July 21, 2021 